\title{
Atypical Presentation of Merkel Cells Carcinoma in Thigh. An Unusual Case
}

\author{
Andrés Limardo ${ }^{1 *}$, Gustavo Prats ${ }^{1}$, Adrían Ortega ${ }^{1}$ and Rubén Padín ${ }^{1,2}$ \\ ${ }^{1}$ Surgeon of Head and Neck, National Hospital Prof. A. Posadas, Argentina \\ ${ }^{2}$ Chief of Head and Neck Surgery, National Hospital Prof. A. Posadas, Argentina
}

Submission: January 30, 2017; Published: May 30, 2017

*Corresponding author: Andrés Constantino Limardo, Surgeon of Head and Neck, National Hospital Prof. A. Posadas, Argentina, Tel: 54911-53149515; Email: andres_limardo@hotmail.com

\begin{abstract}
Background: The Merkel Cells Carcinoma (MCC) is a neuroendocrine carcinoma of the skin. MCC within the lymph nodes in the absence of a primary site is rare and has only been reported sporadically.

Case report: A male patient of 62 years old consults by right inguinal tumor. Lymphadenectomy is made and it informs carcinoma of cells of Merkel. Hidden primary tumor. After 20 months of follow up appears injury to nodular in internal face of right thigh interpreted like primary tumor. Resection is made. We discuss the disease, the diagnosis and the treatment of these tumors.

Conclusion: The Merkel Cells Carcinoma (MCC) is a neuroendocrine carcinoma of the skin. MCC within the lymph nodes in the absence of a primary site is rare and has only been reported sporadically. Our case may represent a lymph node metastasis from an occult or regressed skin primary, but we cannot preclude the possibility of a primary nodal tumor. It is not known until today as it is "the best" therapeutic choice for these cases
\end{abstract}

Keywords: Tumor of cells of Merkel; Carcinoma of cells of Merkel; Rare Tumors of soft parts .

\section{Introduction}

Merkel Cell Carcinoma (MCC) is a neuroendocrine carcinoma of the skin. Although it is 40 times less common that melanoma malignant has mortality greater than this one, with a $30 \%$ in the CCM as opposed to a $15 \%$ in melanoma [1]. MCC within the lymph nodes in the absence of a primary site is rare and has only been reported sporadically [2]. A case of tumor of cells of Merkel appears next that it make debut in form hides and after 20 months the diagnosis could be confirmed. We discuss the disease, the diagnosis and the treatment of these tumors.

\section{Case Report}

A male patient of 62 years old without relevance antecedents, consult by stony hard tumor in right inguinal region of 2 months of evolution. To the physical examination reveal a mobile and superficial tumor of approximately $35 \times 25 \mathrm{~mm}$. It seems inguinal node. The rest of the physical examination in the genital, anal, gluteal zone and inferior tight does not present alterations. Magnetic Resonance Imaging (MRI) of abdomen, pelvis and thighs is realized. It reveals iso intense tumor to muscle in T1weighted and mildly hyper intense tumor in T2-weightedof $39 \times 28 \mathrm{~mm}$ in right inguinal region on subcutaneous cellular weave. STIR sequences have high signal intensity. Images around are interpreted like normal nodes (Figure 1). Normal Fibro colonoscopy.

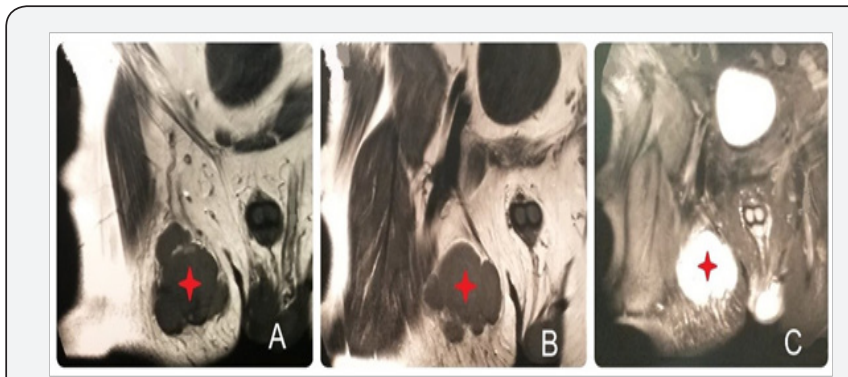

Figure 1: A. Isointense tumor to muscle in T1-weighted. B. Mildly hyper intense tumor in T2-weighted. C. STIR sequences have high signal intensity.

\section{Fine needle aspiration (FNA)}

It impresses a neuroectodermic origin with neoplasia of Merkel for which it is necessary Immunohistochemical study to confirm the diagnosis. Surgery is decided. Biopsy by frozen section is made with general anesthesia that informs atipic cells. Inguinal lymphadenectomy is completed. 


\section{Histology}

Merkel cells carcinoma.

\section{Immunohistochemical study}

Cromogranin, sinaptofibrin, CD56 and 20CK 20positive. The injury is interpreted as metastatic carcinoma of cells of Merkel with hidden primary tumor. Reinforcement with 5800cCy is made by Department of Oncology. After 20 months of follow up it appears a violet nodule on skin in internal face of the right thigh that is interpreted like primary tumor of Merkel.

\section{Ultrasound of hi-resolution}

subcutaneous cellular weave heterogeneoustumor of approximately $45 \times 48 \times 27 \mathrm{~mm}$ with central vascularity. The corporal RMI reveals hyper intense tumor in T1-weighted and hypo intense tumor in T2-weighted of $45 \times 35 \times 24 \mathrm{~mm}$ in $\mathrm{T} 1$ in right thigh (Figure 2).

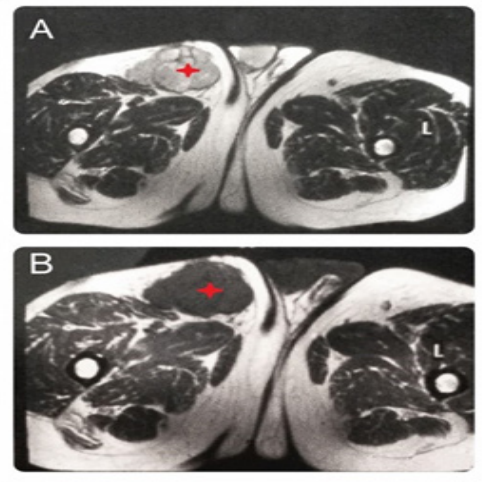

Figure 2: RMI: A. hyper intense tumor in T1-weighted; B. Hypo intense tumor in T2-weighted.
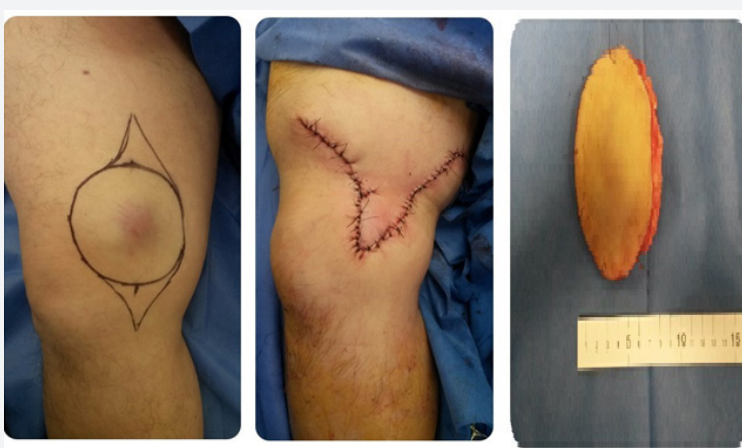

Figure 3: Tumor in right thigh. Histology reveals Merkel cells carcinoma.

FNA is decided that suspicious tumor informs Merkel cells carcinoma with the antecedents. Surgery is decided. Resection with margins is made, $5 \mathrm{~cm}$ lateral and $3 \mathrm{~cm}$ deep and reconstruction with skin local flap (Figure 3). Histology reveals Merkel cells carcinoma confirmed by Immunohistochemical study.

\section{Free margins}

After 24 months of follow up the patient does not present relapses.

\section{Discussion}

The MCC appears in people with an average age of 70 years, although several cases of MCC have been described in which the age was inferior to the awaited one. It is more frequent in people of white skin. According to some authors it predominates in male patients [3]. Sun exposure is thought to play a major role in pathogenesis. It has been observed in many cases that these patients were put under immunosuppression after the transplant of a solid organ, or treated by aplastic anemia, with antithymocyte globulin and cyclosporine [4]. Merkel cell polyomavirus (MCV) is detected in $50 \%$ to $100 \%$ of patient samples. The tumor is located in the dermis, and can extend to the subcutaneous cellular weave and deep soft weaves. Epidermis usually is respected, although it can be ulceror to show hyperplasia reactivates [5].

MCC express the markers of epithelial origin and neuroendocrine type. The MCC express markers of epithelial origin (CK 20) and neuroendocrine type (NSE, Cromogranin B and $A$; neurofilament $L$ and polypeptide $M$ ) and TTF1 negative to differentiate these tumors from metastatic small-cell lung cancer [5].It has been used for the diagnosis of the tumor the cytology by fine needle aspiration [6].

Clinically the MCC appears typically like primary a cutaneous injury $(75 \%)$, although it can make debut as a metastatic disease [7]. There are currently two possible explanations for what occurred in our patient. First, the inguinal mass could be a massively enlarged lymph node where precursor cells became neoplastic. This would be consistent with a presumptive diagnosis of primary nodal disease. Alternatively, an initial skin lesion could have spontaneously regressed and the inguinal mass represents a single site of metastasis. After 20 months of follow up it appears a lesion on skin in internal face of the right thigh that is interpreted like primary tumor of Merkel. So we concluded the patient had MCC with inguinal nodes metastasis. But it was an atypical presentation. The primary injury usually is painless, sobrehigh, of fast growth. That appears like a solitary red-violet nodule or papule with telangiectasia in surface, reason [5]. Tumors sizes oscillates between 0.5 and $5 \mathrm{~cm}$ (generally, minor of $2 \mathrm{~cm}$ ) and usually are not ulcer. It can evolve badly to a red-violet plate.

In the presence of a nodal Merkel cell tumor, an exhaustive clinico-radiologic search for a primary tumor must be carried out [7]. MRI of abdomen, pelvis and thighs is realized and Fibro colonoscopy was made in our patient.

To respect to the surgery three subjects are due to discuss: the extension of margins, sentinel lymph node biopsy, as well 
as nodes dissection. Recommends margins of $3 \mathrm{~cm}$ and depth $2 \mathrm{~cm}$ when it is possible [8]. The Mohs surgery followed of radiotherapy are used in small injuries [8]. Are data no available on the utility of the study of the sentinel lymph node in these tumors?

The sentinel lymph node biopsy is recommended in equal or greater injuries of $1 \mathrm{~cm}$, by the risk to nodal metastatic and with node dissection in case of positive. With respect to the Radiotherapy, we know that they are sensible tumors. It have been documented complete answer of the measurable tumor of $96 \%$, and $4 \%$ of partial answer (rate global answer of the $100 \%$ ) [9]. The adjuvant Radiotherapy has shown to improve local recurrence and average survival. It does not seem necessary in the cases where the resection is complete, although it is recommended in the cases with affected margins, incomplete extirpation or in cases in which the surgery accomplishment is impossible. The use of adjuvant radiotherapy or as only treatment in non-surgical stages has demonstrated to increase the survival [9]. The chemotherapy in this tumor does not increase the survival and causes considerable toxicity, advising itself solely in patients with remote metastatic where the loco regional treatment has not controlled. Immunotherapy targeting the programmed cell death receptor 1 /programmed cell death ligand1 (PD-1/PD-L1) checkpoint holds great promise in treating advanced MCC and may provide durable responses in a portion of patients [10].Despite, the handling individualized in each patient is recommended [9].

\section{Conclusion}

The Merkel Cells Carcinoma (MCC) is a neuroendocrine carcinoma of the skin. MCC within the lymph nodes in the absence of a primary site is rare and has only been reported sporadically. Our case may represent a lymph node metastasis from an occult or regressed skin primary, but we cannot preclude the possibility of a primary nodal tumor. It is not known until today as it is "the best" therapeutic choice for these cases.

\section{Conflict of Interest}

Andrés C. Limardo declares that he has no conflict of interest, Gustavo Prats declares that he has no conflict of interest, Adrían Ortega declares that he has no conflict of interest, Rubén Padín declares that he has no conflict of interest.

\section{Compliance with Ethical Standards}

Funding: No required
Ethical approval (humans): All procedures performed in studies involving human participants were in accordance with the ethical standards of the institutional and/or national research committee and with the 1964 Helsinki declaration and its later amendments or comparable ethical standards.

Ethical approval (animals): This article does not contain any studies with animals performed by any of the authors.

Informed consent: Informed consent was obtained from all individual participants included in the study.

\section{Number of Figures: 3}

\section{References}

1. Poulsen M (2004) Merkel-cell carcinoma of the skin. Lancet Oncol 5(10): 593-599.

2. Kim EJ, Kim HS, Kim HO, Jung CK, Ko YH, et al. (2009) Merkel cell carcinoma of the inguinal lymph node with an unknown primary site. J Dermatol 36(3): 170-173.

3. Paradela S, Peña C, Fernández-Jorge B, Vieira V, Rodríguez-Lozano J, et al. (2004) Actas Dermosifiliogr 95: 553-559.

4. Zwald F, Leitenberger J, Zeitouni N, Soon S, Brewer J, et al. (2016) Recommendations for Solid Organ Transplantation for Transplant Candidates With a Pretransplant Diagnosis of Cutaneous Squamous CellCarcinoma, Merkel Cell Carcinoma and Melanoma: A Consensus Opinion From the International Transplant Skin Cancer Collaborative (ITSCC). Am J Transplant 16(2): 407-413

5. Medina-Franco H, Urist MM, Fiveash J, Heslin MJ, Bland KI, et al. (2001) Multimodality treatment of Merkel cell carcinoma: case series and literature review of 1024 cases. Ann Surg Oncol 8(3): 204-208.

6. Bechert CJ, Schnadig V, Nawgiri R (2013) The Merkel cell carcinoma challenge: a review from the fine needle aspiration service. Cancer Cytopathol 121(4): 179-188

7. Quiroz-Sandoval O, Cuellar-Hubbe M, Lino-Silva L, Salcedo-Hernández R, López-Basave H, et al. (2016) Primary retroperitoneal Merkel cell carcinoma: Case report and literature review. Int J Surg Case Rep 19: 21-24.

8. Brummer GC, Bowen AR, Bowen GM (2016) Merkel Cell Carcinoma: Current Issues Regarding Diagnosis, Management, and Emerging Treatment Strategies. Am J Clin Dermatol 17(1): 49-62.

9. Cassler NM, Merrill D, Bichakjian CK, Brownell I (2016) Merkel Cell Carcinoma Therapeutic Update. Curr Treat Options Oncol 17(7): 36.

10. Banks PD, Sandhu S, Gyorki DE, Johnston ML, Rischin D (2016) Recent Insights and Advances in the Management of Merkel Cell Carcinoma. J Oncol Pract 12(7): 637-646. 

(C) (1) This work is licensed under Creative DOI: 10.19080/JOJCS.2017.02.555598

\section{Your next submission with Juniper Publishers} will reach you the below assets

- Quality Editorial service

- Swift Peer Review

- Reprints availability

- E-prints Service

- Manuscript Podcast for convenient understanding

- Global attainment for your research

- Manuscript accessibility in different formats

( Pdf, E-pub, Full Text, Audio)

- Unceasing customer service

Track the below URL for one-step submission https://juniperpublishers.com/online-submission.php 